\title{
Three novel variants in the arylsulfatase A (ARSA) gene in patients with metachromatic leukodystrophy (MLD)
}

\author{
D. Hettiarachchi* ${ }^{*}$ and V. H. W. Dissanayake
}

\begin{abstract}
Objective: To describe the genetic variants in the ARSA gene in Sri Lankan patients with metachromatic leukodystrophy (MLD). As the variant profile of MLD in the Sri Lankan population is currently unknown.

Results: Twenty patients from eighteen Sri Lankan families were screened for ARSA gene mutations. We found 13 different genetic variants of these three were novel. The three novel variants were p.Asp281Asn, p.Asp283Asn, p.Ala344Asp. Seven patients out of 20 were also positive for the pseudodeficiency (PD) allele c.1049A>G (p.Asn350Ser). This is the first report to describe the molecular genetic variants of Sri Lankan patients with MLD.
\end{abstract}

Keywords: Metachromatic leukodystrophy, ARSA, Neurodegenerative disorders

\section{Introduction}

Metachromatic leukodystrophy (MLD; OMIM \#250,100) is a rare neurodegenerative disorder resulting in a deficiency of arylsulfatase A activity (ARSA, EC 3.1.6.8). This autosomal recessive condition has an incidence of 1 in 40,000 live births [1]. ARSA is a lysosomal enzyme involved in cerebroside sulfate degradation. Hence its deficiency results in the accumulation of cerebroside3 -sulfate in the lysosomes of the tissues of the central and peripheral nervous system [2]. High levels of sulfide cause progressive demyelination and loss of white matter with clinical features of neurodegeneration. MLD is classified in three subtypes depending on the age of onset as; infantile ( $0-2$ years); juvenile with subtypes of early (3-6 years) and late juvenile (7-16) and adult. The onset of the adult form is after sexual maturity, sometimes not until the fourth or fifth decade of life [3].

MLD is known to result from a homozygous or a compound heterozygous mutation in the arylsulfatase A gene on chromosome 22q13. It's a small gene of about $3 \mathrm{~kb}$ with eight exons encoding a 507 amino-acid precursor (GenBank accession numbers, NM_000487.4 and NP_000478.2) [4,

*Correspondence: dineshani@anat.cmb.ac.lk

Human Genetics Unit, Faculty of medicine, University of Colombo, 25,

Kynsey Place, Colombo 08, Sri Lanka
5]. This gene is transcribed into one major and two minor mRNA species of 2.1, 3.7 and $4.8 \mathrm{~kb}$ respectively [6]. Thus far 186 mutations in the ARSA gene have been reported among them 181 variants are directly associated with MLD (http://www.hgmd.cf.ac.uk/ac/gene.php?gene=ARSA). However, the variant spectrum in Sri Lanka is not known. Additionally, there are neutral variants known as the ARSA pseudodeficiency $(\mathrm{Pd})$ allele where there is a reduction of ARSA activity. Here we describe the genetic variants in the ARSA gene in Sri Lankan patients with metachromatic leukodystrophy (MLD) as it is currently unknown.

\section{Main text \\ Methods \\ Patients}

Twenty patients from eighteen families were screened for ARSA gene mutations. Patients were recruited from the Human Genetics Unit (HGU), faculty of medicine university of Colombo and Asiri Surgical Hospital center for genomics. Based on the expert neurological opinion, neuroimaging findings such as Magnetic resonance imaging (MRI) studies and clinical diagnosis of MLD.

\section{Molecular genetic analysis}

Following written informed consent, the patient's genomic DNA was extracted from the patient's whole 
blood samples collected in K3EDTA tubes. DNA extraction was carried out using the QIAamp DNA Blood Mini Kit; Qiagen, according to the manufacturer's protocol. The full length of the ARSA gene including coding exons and corresponding intron/exon boundaries were amplified by seven forward and reverse primer sets [7].

Amplified PCR fragments were checked by agarose gel electrophoresis to ensure it meets the quality criteria required to produce an accurate result. Then PCR fragments were subjected to sanger sequencing using the BigDye ${ }^{\circledR}$ Terminator v3.1 Cycle Sequencing Kit by Applied Biosystems ${ }^{\circledR} 3130$ Genetic Analyzer followed by ethanol purification. The resulted ABI files were analyzed using codon code aligner software aligning with a human ARSA reference sequence obtained from ENSEMBLE database. Selection of the pathogenic and likely pathogenic variants and removing the benign variants from available variants in the patients. This was carried out using the information available on prior publications, data from population frequency databases and clinical databases.

\section{Results}

We studied twenty patients from 18 unrelated families, all the patients were of Sri Lankan origin and referred to us from all parts of the island. The median age at diagnosis was 19.9 years (range $=0.8-40$ ). The clinical categories were as follows infantile 7; early juvenile 1 ; late juvenile 2 and adult 10 . We found 13 different amino acid changes in these three were novel (p.Asp281Asn, p.Asp283Asn, p.Ala344Asp) (Table 1). Seven patients out of 20 were positive for the pseudodeficiency (PD) allele c.1049A $>\mathrm{G}$

Table 1 Genetic variants in the ARSA gene in Sri Lankan patients with MLD

\begin{tabular}{|c|c|c|c|c|c|c|}
\hline $\begin{array}{l}\text { Patient } \\
\text { number }\end{array}$ & $\begin{array}{l}\text { Age range } \\
\text { at diagnosis } \\
\text { (years) }\end{array}$ & Phenotype & $\begin{array}{l}\text { Nucleotide } \\
\text { substitution }\end{array}$ & Amino acid change & Zygosity & $\begin{array}{l}\text { Pseudo } \\
\text { deficiency } \\
\text { allele }\end{array}$ \\
\hline 01 & $0-5$ & Infantile & $\begin{array}{l}\text { c. } 342 C>T \\
\text { c. } 1055 A>G\end{array}$ & $\begin{array}{l}\text { p.Arg114X } \\
\text { p.Asn350Ser }\end{array}$ & Compound heterozygote & Present \\
\hline 02 & $6-10$ & Late juvenile & $\begin{array}{l}\text { c.342C>T } \\
\text { c. } 601 T>C\end{array}$ & $\begin{array}{l}\text { p.Arg114X } \\
\text { p.Tyr201His }\end{array}$ & Compound heterozygote & No \\
\hline 03 & $0-5$ & Infantile & $\begin{array}{l}\text { c. } 1055 A>G \\
\text { c. } 1109 G>A\end{array}$ & $\begin{array}{l}\text { p.Asn350Ser } \\
\text { pArg370GIn }\end{array}$ & Compound heterozygote & Present \\
\hline 04 & $0-5$ & Infantile & $\begin{array}{l}\text { c. } 841 G>A \\
\text { c. } 1055 A>G\end{array}$ & $\begin{array}{l}\text { p.Asn350Ser } \\
\text { p.Asp281Asn }\end{array}$ & Compound heterozygote & Present \\
\hline 05 & $36-40$ & Adult & $\begin{array}{l}\text { c. } 1055 A>G \\
\text { c. } 1115 G>A\end{array}$ & $\begin{array}{l}\text { p.Asn350Ser } \\
\text { and } \\
\text { p.Arg372Gln }\end{array}$ & Compound heterozygote & Present \\
\hline 06 & $40-45$ & Adult & $\begin{array}{l}\text { c. } 1055 A>G \\
c .1115 G>A\end{array}$ & $\begin{array}{l}\text { p.Asn350Ser } \\
\text { and } \\
\text { p.Arg372Gln }\end{array}$ & Compound heterozygote & Present \\
\hline 07 & $0-5$ & Infantile & $\begin{array}{l}c .251 C>T \\
c .847 G>A\end{array}$ & $\begin{array}{l}\text { p.Pro84Lys } \\
\text { p.Asp283Asn }\end{array}$ & Compound heterozygote & No \\
\hline 08 & $6-10$ & Early juvenile & $\begin{array}{l}\text { C. } 1178 C>G \\
\text { c. } 1425 C>A\end{array}$ & $\begin{array}{l}\text { p.Thr393Ser } \\
\text { p.Ala344Asp }\end{array}$ & Compound heterozygote & No \\
\hline 09 & $0-5$ & Infantile & $\begin{array}{l}\text { C. } 1178 C>G \\
\text { c. } 1425 C>A\end{array}$ & $\begin{array}{l}\text { p.Thr393Ser } \\
\text { p.Ala344Asp }\end{array}$ & Compound heterozygote & No \\
\hline 10 & $0-5$ & Infantile & c.938G >A & p.Arg313Gln & Homozygote & No \\
\hline 11 & $30-35$ & Adult & $c .251 C>T$ & p.Pro84Lys & Heterozygote & No \\
\hline 12 & $30-35$ & Adult & $\mathrm{c} .847 \mathrm{G}>\mathrm{A}$ & p.Asp283Asn & heterozygote & No \\
\hline 13 & $0-5$ & Infantile & $\begin{array}{l}c .256 C>T \\
c .847 G>A\end{array}$ & p.Arg86Trpp.Asp283Asn & Compound heterozygote & No \\
\hline 14 & $36-40$ & Adult & c. $251 C>T$ & p.Pro84Lys & Heterozygote & No \\
\hline 15 & $6-10$ & Late juvenile & C. $1178 C>G$ & p.Thr393Ser & Heterozygote & No \\
\hline 16 & $30-35$ & Adult & c. $1055 A>G$ & p.Asn350Ser & Heterozygote & Present \\
\hline 17 & $36-40$ & Adult & c. $1055 A>G$ & p.Asn350Ser & Heterozygote & Present \\
\hline 18 & $30-35$ & Adult & $\begin{array}{l}\text { C. } 346 C>T \\
\text { c. } 1178 C>G\end{array}$ & $\begin{array}{l}\text { p.Arg116Ter } \\
\text { p.Thr393Ser }\end{array}$ & Heterozygote & No \\
\hline 19 & $40-45$ & Adult & c. $346 C>T$ & p.Arg116Ter & Heterozygote & No \\
\hline 20 & $30-35$ & Adult & $\begin{array}{l}\text { c. } 346 C>T \\
\text { c. } 1178 C>G\end{array}$ & $\begin{array}{l}\text { p.Arg116Ter } \\
\text { p.Thr393Ser }\end{array}$ & Heterozygote & No \\
\hline
\end{tabular}


and showed a corresponding p.Asn350Ser amino acid change and low ARSA enzyme activity.

\section{Discussion}

In our study, we found three novel amino acid changes p.Asp281Asn, p.Asp283Asn, p.Ala344Asp in the ASA protein. All three novel variants in the Sri Lankan population were compound heterozygous variants and were $\mathrm{A}>\mathrm{G}, \mathrm{G}>\mathrm{A}$ and $\mathrm{C}>\mathrm{A}$ transitions respectively. Among the patients who were positive for the pseudodeficiency (PD) allele c.1049A $>$ G, p.Asn350Ser, five of them were compound heterozygous for the mutation and only two were heterozygous. The high frequency of the common PD allele was observed in the Sri Lankan population in line with already published data in other populations $[8,9]$. The second most frequent mutation found in our study was c.1178C >G, p.Thr393Ser this mutation was found in almost all the clinical subcategories of MLD from juvenile to adult form. Other common mutations were p.Pro84Lys, p.Asp283Asn and p.Arg116Ter with three unrelated patients to each variant. Among these p.Pro84Lys and p.Arg116Ter has been reported to be pathogenic in other populations. However p.Asp283Asn has not been reported elsewhere Asp281 is highly conserved among arylsulphatases and its crystal structure shows an essential catalytic site which provides a magnesium ion binding site within the protein, we predict the change from aspartate to asparagine from a negatively charged amino acid to a polar amino acid (containing an amide group) disrupts the catalytic binding site to magnesium ions by adversely affecting protein folding. Other amino acid changes observed in two unrelated individuals each were p.Arg114X, p.Arg372Gln and p.Ala344Asp. Mutation p.Arg114X leads to an early stop codon with a resultant truncated ARSA polypeptide that is 114 amino acids long. Truncated proteins are classified as pathogenic according to ACMG guidelines [10]. This study has shed light on the molecular genetic variants found in MLD that have not been previously reported and given the diversity of the population this knowledge will add further to the understanding and timely diagnosis of MLD.

\section{Limitations}

- This study only concentrates on patients clinically diagnosed to have MLD who underwent genetic testing.

- It is only a descriptive study of the variant profile in Sri Lankan patients.

- The effect of these variants on individual patients and their future treatment options needs to be considered.
- Functional studies and family member screening need to be performed to ascertain the exact pathogenicity of the novel variants.

\section{Abbreviations \\ MLD: metachromatic leukodystrophy; ARSA: arylsulfatase A gene; HGU: Human Genetics Unit. \\ Acknowledgements \\ We wish to acknowledge the referring doctors and the laboratory staff for their contribution.}

\section{Authors' contributions}

DH wrote the first draft of the manuscript with contributions from VHWD. Both authors read and approved the final manuscript.

\section{Funding \\ No funding for this project}

\section{Availability of data and materials}

Data is not available in a public domain it will be shared on request from interested parties.

\section{Ethics approval and consent to participate}

Ethics approval for the study was obtained by the Faculty of Medicine, University of Colombo Ethics Review Committee and consent for genetic testing was obtained from the parents or guardians of the children.

\section{Consent for publication}

The database is anonymized hence consent for publication was not required according to the Ethics Review Committee decision.

\section{Competing interests}

The authors declare that they have no competing interests.

Received: 13 August 2019 Accepted: 31 October 2019

Published online: 06 November 2019

References

1. Von Figura K. Metachromatic leukodystrophy. Metabol mol basis of inherit dis. 2001.

2. Wang $Z$, et al. Whole-exome sequencing identifies compound heterozygous mutations in ARSA of two siblings presented with atypical onset of metachromatic leukodystrophy from a Chinese pedigree. Clin Chim Acta. 2016;460:135-7.

3. Narayanan DL, et al. Spectrum of ARSA variations in Asian Indian patients with arylsulfatase A deficient metachromatic leukodystrophy. J Hum Genet. 2019:64(4):323-31.

4. Bruns GAP, et al. Expression of human arylsulfatase-A in man-hamster somatic cell hybrids. Cytogenet Genome Res. 1978;22(1-6):182-5.

5. Shukla P, et al. Molecular and structural analysis of metachromatic leukodystrophy patients in Indian population. J Neurol Sci. 2011;301(1-2):38-45.

6. Grossi S, et al. Molecular analysis of ARSA and PSAP genes in twentyone Italian patients with metachromatic leukodystrophy: identification and functional characterization of 11 novel ARSA alleles. Hum Mutat. 2008;29(11):E220-30.

7. Gieselmann V, et al. Arylsulfatase A pseudodeficiency: loss of a polyadenylylation signal and N-glycosylation site. Proc Natl Acad Sci. 1989;86(23):9436-40.

8. Eng B, et al. Identification of nine novel arylsulfatase a (ARSA) gene mutations in patients with metachromatic leukodystrophy (MLD). Hum Mutat. 2003;22(5):418-9.

9. Kreysing J, von Figura K, Gieselmann V. Structure of the arylsulfatase A gene. Eur J Biochem. 1990;191(3):627-31. 
10. Richard S, et al. Standards and guidelines for the interpretation of sequence variants: a joint consensus recommendation of the American College of Medical Genetics and Genomics and the Association for Molecular Pathology. Genet in Med. 2015;17(5):405.

\section{Publisher's Note}

Springer Nature remains neutral with regard to jurisdictional claims in published maps and institutional affiliations.
Ready to submit your research? Choose BMC and benefit from:

- fast, convenient online submission

- thorough peer review by experienced researchers in your field

- rapid publication on acceptance

- support for research data, including large and complex data types

- gold Open Access which fosters wider collaboration and increased citations

- maximum visibility for your research: over $100 \mathrm{M}$ website views per year

At BMC, research is always in progress.

Learn more biomedcentral.com/submissions 